Jurnal Riset Ekonomi dan Bisnis

http://journals.usm.ac.id/index.php/jreb

\title{
SARANA TEKNOLOGI \\ DAN BUDAYA ORGANISASI TERHADAP KEPUASAN KERJA DIMEDIASI SISTEM INFORMASI
}

\begin{abstract}
Harjanto1); Kesi Widjajanti2); L. Rini Sugiarti3)
Harjanto4444@gmail.com ${ }^{1)}$; kesi_widjajanti@yahoo.com ${ }^{2)}$; riendoe@usm.ac.id ${ }^{3)}$

Program Studi Magister Manajemen, Universitas Semarang, Semarang, Indonesia

Info Artikel

Abstrak

Sejarah Artikel:

Diterima :30-11-2020

Disetujui :30-12-2020

Dipublikasikan:31-12-

2020

Keywords:

Means of technology; organizational culture; information systems; job satisfaction

Penelitian ini bertujuan untuk mengetahui apakah terdapat pengaruh Positif dan signifikan antara sarana pendukung teknologi informasi dan budaya organisasi terhadap sitem informasi dan kepuasan kerja. Unit analisis penelitian adalah operator dari poliklinik Biddokkes. Pengumpulan data dilakukan dengan cara membagikan angket berbentuk kuesioner. Responden yang digunakan sebanyak 83 operator. Metode analisis yang digunakan dalam menguji hipotesis adalah Structural Equation Modeling (SEM) dengan menggunakan Partial Least Square (PLS) 3.0. Penelitian ini berhasil membuktikan adanya hubungan yang positif dan signifikan antara sarana pendukung teknologi informasi terhadap kepuasan kerja, sarana pendukung teknologi informasi terhadap sistem informasi, budaya organisasi terhadap sitem informasi dan sistem informasi terhadap kepuasan kerja. Sedangkan hubungan yang positif dan tidak signifikan ditunjukkan oleh hubungan budaya organisasi terhadap kepuasan kerja..
\end{abstract}

\section{TECHNOLOGY MEANS AND CULTURE TOJOB SATISFACTION IS MEDIATED BY INFORMATION SYSTEMS}

\begin{abstract}
This study aims to determine whether there is a positive and significant influence between the means of supporting information technology and organizational culture on information systems and job satisfaction. The unit of research analysis is the operator of Biddokkes polyclinic. Data collection is done by distributing questionnaires in the form of questionnaires. Respondents used were 83 operators. The analytical method used in testing hypotheses is Structural Equation Modeling (SEM) using Partial Least Square (PLS) 3.0. This research succeeded in proving a positive and significant relationship between information technology supporting facilities on job satisfaction, information technology supporting facilities on information systems, organizational culture on information systems and information systems on job satisfaction. While the positive and insignificant relationship is shown by the relationship of organizational culture to job satisfaction.
\end{abstract}

\footnotetext{
Alamat korespondensi : 


\section{PENDAHULUAN}

Sumber daya manusia pada organisasi perlu dikelola secara profesional agar terwujud suatu keseimbangan antara kepuasan pegawai dengan tuntutan dan kemampuan organsiasi. Manusia sebagai faktor tenaga kerja dapat tumbuh dan berkembang dengan baik, bersemangat dalam melakukan aktivitas kerja, maka sangat penting memberi perhatian terhadap keadaan pegawai. Dalam era globalisasi yang semakin maju terbentuk persaingan yang semakin tajam, dimana setiap organisasi dan para pelaku ekonomi hendaknya mampu menyesuaikan diri dengan perubahan yang terjadi, serta memanfaatkan peluang dan tantangan yang muncul. Untuk mencapai tujuan organisasi diperlukan sebuah asas dimana pegawai dapat terpenuhi segala aspek kebutuhannya.

Salah satu hal yang penting dalam pengelolaan sumber daya manusia adalah kepuasan kerja. Kepuasan kerja mempunyai peran penting dalam rangka mendukung tercapainya tujuan organisasi. Beberapa penelitian terdahulu meneliti tentang faktor-faktor yang mempengaruhi kinerja perusahaan memiliki perbedaan hasil. Penelitian Rosnidah (2010), Ibrahim dan Dahlias (2016) dan Rasyid (2017) dengan menggunakan variabel Sarana Pendukung Teknologi Informasi sebagai pengaruh terhadap kepuasan kerja menghasilkan pengaruh positif, Sedangkan penelitian yang dilakukan oleh Sugiyanto dan Santoso (2018) Sarana Pendukung Teknologi Informasi memiliki pengaruh negatif terhadap Kepuasan Kerja. Begitu pula dengan penelitian pengaruh Budaya Organisasi terhadap Kepuasan Kerja, terjadi ketidak konsistenan terhadap hasil dari penelitian. Penelitian pengaruh Budaya Organisasi Terhadap Kepuasan Kerja terjadi pada penelitian yang dilakukan oleh Mustika dan Utomo (2013) serta Ali dan Agustian (2018) menghasilkan budaya organisasi berpengaruh positif terhadap Kepuasan Kerja. Sedangkan pada penelitian lain yang dilakukan oleh Paramita, Suharnomo dan Perdhana (2016) Budaya Organisasi memiliki pengaruh yang negatif terhadap Kepuasan Kerja.

Sejak munculnya Corona Virus Disease 2019 (Covid-19), kasus ini terus bertambah hingga akhirnya diketahui bahwa penyebab kluster pneumonia ini adalah novel Corona virus. Saat ini, semua kalangan masyarakat melakukan pencegahan terhadap penularan virus corona yang sangat membahayakan masyarakat pegawai yang ada di kantor pemerintahan. Operator Polikinik yang tergabung pada instansi pemerintahan sedang mengalami kendala terhadap target yang telah menjadi standar ketepatan pendistribusian obat dan alat kesehatan (sarana kesehatan) ke Poliklinik. Target pendistribusian yang seharusnya berada pada angka $100 \%$, Operator Poliklinik belum mampu merealisasikan target tersebut.

Berdasarkan fenomena gap dan research gap di atas, maka dalam penelitian ini diajukan variabel Sistem Informasi sebagai variabel mediasi yang diharapkan dapat menguraikan masalah gap penelitian. Rumusan masalah dalam penelitian ini adalah Bagaimana meningkatkan kepuasan kerja pada Operator Poliklinik instansi pemerintahan dengan sistem informasi sebagai mediasi melalui sarana pendukung teknologi informasi dan budaya organisasi.. Rincian tujuan penelitian sebagai berikut: menganalisis apakah Sarana pendukung teknologi informasi berpengaruh terhadap Kepuasan Kerja, menganalisis apakah Budaya organisasi berpengaruh terhadap Kepuasan Kerja, menganalisis apakah Sarana pendukung teknologi informasi berpengaruh terhadap Sistem informasi, menganalisis apakah Budaya organisasi berpengaruh terhadap Sistem informasi, menganalisis apakah Sistem informasi berpengaruh terhadap Kepuasan Kerja. 


\section{TELAAH PUSTAKA}

Kepuasan kerja merupakan perasaan yang menyokong atau tidak menyokong diri pegawai yang berhubungan dengan pekerjaan maupun dengan kondisi kerjanya. Sehingga kepuasan kerja adalah cerminan perasaan pegawai terhadap pekerjaannya. Hal ini akan tampak dalam sikap positif pegawai terhadap pekerjaan yang dihadapinya dan terhadap organisasinya. Sebaliknya pegawai yang tidak puas akan bersikap negatif terhadap pekerjaannya dalam bentuk yang berbeda satu dengan lainnya (Abdirahman et al., 2018). Kepuasan kerja merupakan refleksi dari pekerjaan yang memberi nilai positif. Jika kita melihat seseorang puas dengan suatu obyek, kita artikan bahwa obyek itu memberikan nilai positif bagi orang tersebut. Berdasarkan uraian di atas dapat disimpulkan bahwa kepuasan kerja pegawai adalah suatu sikap yang positif yang menyangkut penyesuaian diri yang sehat dari para pegawai terhadap kondisi dan situasi kerja, termasuk di dalamnya upah, kondisi sosial, kondisi fisik dan kondisi psikologis. Penelitian ini akan menggunakan indikator kepuasan kerja pegawai menurut Robbins dan Judge (2012), yaitu sifat pekerjaan, pengawasan, gaji, peluang promosi, dan hubungan dengan rekan kerja.

Sistem Informasi merupakan transaksi memproses, mencatat, menggunakan aplikasi pemrosesan data elektronik yang berfokus pada perkembangan aplikasi bisnis yang menyediakan laporan bagi manajemen informasi yang berguna bagi pengambilan keputusan (O'Brien \& Marakas, 2010). Fendini (2013) berpendapat bahwa sistem informasi adalah suatu sistem yang komponennya saling berhubungan di dalam organisasi untuk menunjang pengambilan keputusan dan penyajian informasi, serta pengawasan dan pengendalian terhadap organisasi. Dari pendapatpendapat diatas dapat dimpulkan bahwa system informasi adalah sebuah sitem yang akan mempermudah indivdu dalam organisasi memperoleh informasi yang ada pada organisasi tersebut. Berdasarkan uraian tersebut mengenai indikator Sistem Informasi, maka dalam penelitian ini indikator Sistem Informasi yang digunakan menurut Nelson et al. (2005) antara lain Reabilitas Sistem, Fleksibilitas Sistem, Integrase Sistem, Aksesibilitas Sistem, serta Waktu Respon Sistem.

Pemanfaatan teknologi sebagai manfaat yang diharapkan oleh pengguna sistem informasi dalam melaksanakan tugasnya dimana pengukurannya berdasarkan pada intensitas pemanfaatan, frekuensi pemanfaatan dan jumlah aplikasi atau perangkat lunak yang digunakan. Implementasi teknologi informasi digunakan untuk membantu dalam pencapaian strategi organisasi (Rahmawati, 2010). Dengan demikian dapat disimpulkan bahwa memanfaatkan teknologi informasi merupakan akses terhadap proses bisnis organisasi yang dapat dilakukan dengan cepat sehingga pengambilan keputusan dapat dilakukan secara lebih cepat dan akurat dan pada akhirnya tujuan organisasi dapat tercapai. Berdasarkan uraian di atas mengenai indikator Sarana Pendukung Teknologi Informasi tersebut, maka dalam penelitian ini indikator Sarana Pendukung Teknologi Informasi yang digunakan menurut Pariyatin (2015) antara lain Kualitas Perangkat, Kesiapan Jaringan, dan Pelatihan SDM.

Budaya organisasi merupakan norma, nilai-nilai, asumsi, kepercayaan, filsafat, kebiasaan organisasi, dan sebagainya (isi budaya organisasi) yang dikembangkan dalam waktu yang lama oleh pendiri, pemimpin, dan anggota organisasi yang disosialisasikan dan diajarkan kepada anggota baru serta diterapkan dalam aktivitas organisasi sehingga mempengaruhi pola pikir, sikap, dan perilaku anggota organisasi dalam memproduksi produk, melayani para konsumen, dan mencapai tujuan organisasi (Wirawan, 2015). Bersadarkan dari uraian berbagai pakar diatas, dapat disimpulkan bahwa budaya yang kuat akan mempengaruhi tolak ukur bagi pegawai dalam mencapai tujuan organisasi, sehingga perlu dikondisikan budaya yang kuat untuk terus melekat pada setiap pribadi pegawai. Jika budaya yang kuat dapat terkondisi dengan baik akan mendukung terhadap pencapaian tujuan organisasi. Berdasarkan uraian tersebut mengenai indikator budaya organisasi, maka dalam penelitian ini indikator budaya organisasi yang 
digunakan menurut Wibowo (2014) antara lain Inisiatif perseorangan, Toleransi terhadap risiko, Control (pengawasan), Dukungan manajemen serta Pola komunikasi.

\section{Hubungan Sarana Pendukung Teknologi Informasi Terhadap Kepuasan Kerja}

Menurut Rivai (2011) faktor yang dapat mempengaruhi kepuasan kerja pegawai yaitu faktor intrinsik dan ekstrinsik. Faktor ekstrinsik menyangkut hal-hal yang berasal dari luar diri pegawai, diantaranya yaitu fasilitas kerja. Fasilitas kerja merupakan sarana pendukung dalam aktivitas organisasi berbentuk fisik.Meningkatnya perkembangan lingkungan teknologi membawa konsekuensi terjadinya perubahan kondisi internal organisasi.Sarana teknologi informasi merupakan bagian dari lingkungan fisik kerja yang wajib untuk dimiliki organisasi untuk mempermudah pegawai dalam bekerja. Hasil penelitian yang dilakukan oleh Rosnidah (2012) menghasilkan sarana pendukung teknologi informasi berpengaruh positif dan signifikan tehadap kepuasan kerja.

Mengacu pada uraian di atas maka hipotesis yang dikembangkan adalah sebagai berikut :

H1 : Sarana Pendukung Teknologi Informasi berpengaruh terhadap Kepuasan Kerja.

\section{Hubungan Budaya Organisasi Terhadap Kepuasan Kerja}

Budaya organisasi merupakan norma yang dikembangkan dalam waktu yang lama oleh pendiri, pemimpin, dan anggota organisasi yang disosialisasikan dan diajarkan kepada anggota baru serta diterapkan dalam aktivitas organisasi, sehingga mempengaruhi pola pikir, sikap, dan perilaku anggota organisasi dalam memproduksi produk, melayani para konsumen, dan mencapai tujuan organisasi (Wirawan, 2013). Dengan budaya organisasi yang baik, maka akan dapat meningkatkan kepuasan kerja dari pegawai. Hasil penelitian yang dilakukan oleh Mustika dan Utomo (2013) menghasilkan budaya organisasi berpengaruh positif tehadap kepuasan kerja. Mengacu pada uraian di atas maka hipotesis yang dikembangkan adalah sebagai berikut :

H2 : Budaya Organisasi berpengaruh terhadap Kepuasan Kerja.

\section{Hubungan Sarana Pendukung Teknologi Informasi Terhadap Sistem Informasi}

Menurut Setiawan (2012) Sistem informasi manajemen dengan teknologi informasi sangat berhubungan, karena keduanya bergerak dibidang informasi (pengolahan) danteknologi informasi merupakan bagian dari sistem informasi. Karena system informasi dapat tersusun oleh beberapa teknologi informasi. Sehingga apabila teknologi informasi mengalami kerusakan maka mempengaruhi Sistem informasi atau sistem informasi juga akan mengalami gangguan. Hasil penelitian yang dilakukan oleh Setiawan (2012) menghasilkan sarana pendukung teknologi informasi berpengaruh positif tehadap sitem informasi.

Mengacu pada uraian di atas maka hipotesis yang dikembangkan adalah sebagai berikut :

H3 : sarana pendukung teknologi informasi berpengaruh terhadap sitem informasi.

\section{Hubungan Budaya Organisasi Terhadap Sistem Informasi}

Budaya organisasi selalu dapat ditemukan melekat dalam sistem informasi organisasi (Laudon, 2004). Menurut Ramadhan (2017) Sistem informasi ditentukan oleh hubungan antara system informasi, orang, proses bisnis dan budaya organisasi.Bahkan keberhasilan sistem informasi tidak hanya diukur melalui efisiennya dalam meminimalisir biaya, waktu dan penggunaan sumber daya informasi,tetapi melibatkan juga budaya organisasi. Sehingga budaya organisasi merupakan sesuatu yang dapat menentukan system informasi berjalan secara lancar. Hasil penelitan yang dilakukan oleh Bachmid (2016) menghasilkan budaya organisasi berpengaruh positif terhadap sitem informasi.

Mengacu pada uraian di atas maka hipotesis yang dikembangkan adalah sebagai berikut : 
H4 : budaya organisasi berpengaruh terhadap sitem informasi.

\section{Hubungan Sistem Informasi Terhadap Kepuasan Kerja}

Seseorang merasa puas terhadap sistem informasi tersebut mudah untuk digunakan, maka dia akan menggunakannya.Sebaliknya jika seseorang merasa percaya bahwa sistem informasi tidak memuaskan, maka dia tidak akan menggunakannya. Jogiyanto (2007) berpendapat bahwa kepuasan yang dialami seseorang pengguna merupakan respon yang dikeluakan terhadap system informasi. Sehingga dapat diartikan bahwa kepuasan kerja merupakan respon atau sikap yang dikeluarkan pegawai terhadap system informasi sehingga penggunaannya tepat. Hasil penelitan yang dilakukan oleh Saputro (2008) menghasilkan sitem informasi berpengaruh positif terhadap kepuasan kerja.

Mengacu pada uraian di atas maka hipotesis yang dikembangkan adalah sebagai berikut :

H5 : Sistem informasi berpengaruh terhadap kepuasan kerja

\section{Model Penelitian}

Temuan mengenai fenomena gap dan research gap pada pendahuluan yang dilakukan pada studi ini mengembangkan sebuah model penelitian empiris mengenai Kepuasan Kerja. Pada studi ini, besar kecilnya Kepuasan Kerja dijelaskan oleh variabel Sarana Pendukung Teknologi Informasi dan Budaya Organisasi dengan dimediasi oleh Sistem Informasi.

Visualisasi mengenai keterpengaruhan variabel-variabel tersebut disajikan dalam gambar berikut ini:

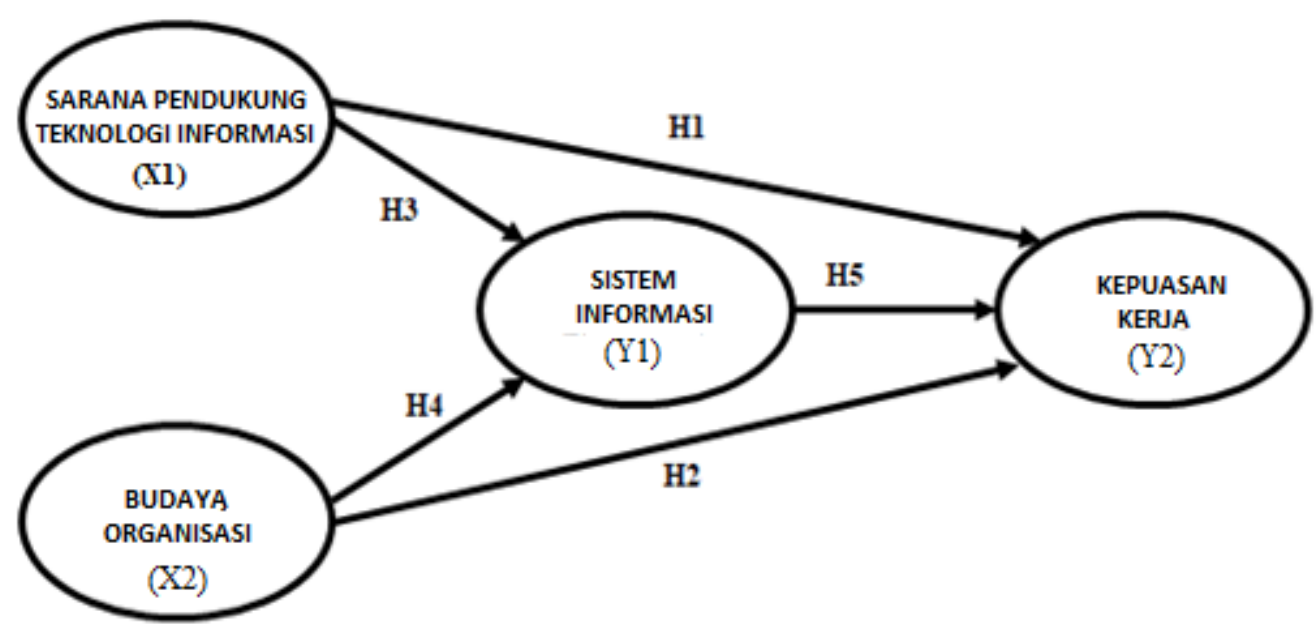

Gambar 1. Model penelitian

\section{METODE}

Jenis penelitian adalah explanative research. Sumber data yang digunakan dalam penelitian ini adalah data primer. Teknik pengambilan sampel yang digunakan dalam penelitian ini adalah populasi yang berjumlah 83 operator poliklinik yang berpengaruh langsung terhadap kegiatan pendistribusian.

Metode pengumpulan data yang digunakan adalah dengan cara menyebar angket atau kuesioner secara personal. Kuesioner merupakan sekelompok pertanyaan yang diformulasikan secara tertulis dengan tujuan untuk mencari pendapat responden, dan biasanya jawaban disediakan dalam bentuk alternatif yang hampir serupa. Dalam penelitian ini di gunakan skala 
interval yang urutan skala 1 (Sangat Tidak Setuju) sampai dengan angka 7 (Sangat Setuju), serta semantik deferensial untuk semua variabel.

Metode analisis data yang diterapkan dalam proses penelitian ditentukan oleh metode penelitian kuantitatif, yaitu dengan mengolah data yang diperoleh dari hasil jawaban kuesioner dalam bentuk angka-angka untuk digunakan dalam analisis data. Penelitian ini membutuhkan suatu analisis data dan interpretasinya yang digunakan untuk menjawab pertanyaan-pertanyaan penelitian dalam mengungkapkan fenomena social tertentu.

\section{HASIL DAN PEMBAHASAN}

Teknik analisis yang digunakan dalam penelitian ini adalah Partial Least Square (PLS) yaitu SEM yang berbasis variance, dengansoftwarestatistik SmartPLS untuk menguji hubungan antara variabel, baik sesama variabel latent maupun dengan variabel indikator.

\section{Model Struktural (inner model)}

Model struktural dibentuk berdasarkan teori dan hasil-hasil penelitian empiris (penelitian terdahulu), yaitu penelitian-penelitian mengenai pengaruh Sarana pendukung teknologi informasi dan budaya organisasi terhadap Kepuasan Kerja dengan sistem informasi sebagai variabel intervening, yang dapat dilihat pada Tabel 1 berikut ini.

Tabel 1. Hasil PLS Algorithm

\begin{tabular}{|l|l|l|l|l|}
\hline & SPTI & BO & SI & Kep \\
\hline X11 & 0,815 & & & \\
\hline X12 & 0,892 & & & \\
\hline X13 & 0,891 & & & \\
\hline X21 & & 0,858 & & \\
\hline X22 & & 0,554 & & \\
\hline X23 & & 0,888 & & \\
\hline X24 & & 0,841 & & \\
\hline X25 & & 0,864 & & \\
\hline Y11 & & & 0,805 & \\
\hline Y12 & & & 0,882 & \\
\hline Y13 & & & 0,808 & \\
\hline Y14 & & & 0,889 & \\
\hline Y15 & & & 0,822 & \\
\hline Y21 & & & & 0,812 \\
\hline Y22 & & & & 0,908 \\
\hline Y23 & & & & 0,851 \\
\hline Y24 & & & & 0,675 \\
\hline Y25 & & & & 0,799 \\
\hline
\end{tabular}

Sumber : data diolah tahun 2020 


\section{Evaluasi Model Pengukuran (outer model)}

Pada Gambar 1 dapat dilihat bahwa model yang digunakan belum bagus dikarenakan terdapat 1 (satu) indikator yang memiliki nilai di bawah standar yaitu di bawah 0,6 yaitu indikator X2.2, sehingga perlu di-drop untuk agar memenuhi standar, seperti pada Tabel 2 berikut ini.

Tabel 2. Revisi Model PLS Algorithm

\begin{tabular}{|c|c|c|c|c|}
\hline & SPTI & BO & SI & Kep \\
\hline $\mathrm{X} 11$ & 0,815 & & & \\
\hline $\mathrm{X} 12$ & 0,892 & & & \\
\hline $\mathrm{X} 13$ & 0,891 & & & \\
\hline $\mathrm{X} 21$ & & 0,875 & & \\
\hline $\mathrm{X} 23$ & & 0,924 & & \\
\hline $\mathrm{X} 24$ & & 0,991 & & \\
\hline $\mathrm{X} 25$ & & 0,844 & & \\
\hline $\mathrm{Y} 11$ & & & 0,804 & \\
\hline $\mathrm{Y} 12$ & & & 0,882 & \\
\hline $\mathrm{Y} 13$ & & & 0,808 & \\
\hline $\mathrm{Y} 14$ & & & 0,889 & \\
\hline Y15 & & & 0,822 & \\
\hline Y21 & & & & 0,812 \\
\hline Y22 & & & & 0,908 \\
\hline Y23 & & & & 0,851 \\
\hline Y24 & & & & 0,675 \\
\hline Y25 & & & & 0,799 \\
\hline
\end{tabular}

Sumber: data diolah tahun 2020

Hasil pengujian setelah revisi model dengan menghilangkan indikator yang tidak memenuhi standar (nilai di bawah 0,5) yaitu indikator X2.2, sehingga semua indikator telah memiliki loading di atas 0,6 .

\section{Validitas dan Reliabilitas Konstruk}

Convergent validity mengukur besarnya korelasi antara skor indikator dengan skor variabelnya. Indikator dianggap valid apabila memiliki nilai AVE (average variance extracted) lebih dari 0,5. Uji reliabilitas dapat dilihat dari nilai composite reliability dan nilai Cronbach's alpha. Kriteria dikatakan reliabel yaitu jika nilai composite reliability lebih dari 0,7 dan nilai Cronbach's alpha lebih dari 0,6.

Tabel 3. Validitas dan Reliabilitas Konstruk

\begin{tabular}{|l|r|r|r|}
\hline & \multicolumn{1}{|c|}{ Cro-A } & \multicolumn{1}{c|}{ Com-Rea } & \multicolumn{1}{c|}{ AVE } \\
\hline SPTI & 0,836 & 0,9 & 0,751 \\
\hline BO & 0,904 & 0,933 & 0,777 \\
\hline SI & 0,897 & 0,924 & 0,709 \\
\hline KEP & 0,869 & 0,906 & 0,66 \\
\hline
\end{tabular}

Sumber: data diolah tahun 2020 
Pada Tabel 3 hasil hitungan diatas, Cronbach's Alpha, rho,A dan AVE telah memenuhi syarat.

\section{Uji R-Square}

Berdasarkan pengolahan data yang telah dilakukan dengan menggunakan program SmartPLS, diperoleh nilai $R$-Square sebagai berikut:

Tabel 4. Nilai $R$-Square

\begin{tabular}{|l|r|}
\hline & R-Square \\
\hline SI & 0,498 \\
\hline KEP & 0,745 \\
\hline
\end{tabular}

Sumber :data diolah tahun 2020

\section{Pengujian Model Struktural (Inner Model)}

Model struktural (inner model) dievaluasi menggunakan $\mathrm{R}^{2}$ untuk variabel endogen/terikat, sedangkan nilai koefisien path/jalur digunakan untuk variabel eksogen/bebas, yang kemudian dinilai signifikansinya berdasarkan nilai t-statistic setiap jalur. Model struktural penelitian ini dapat dilihat pada Gambar 2 berikut.

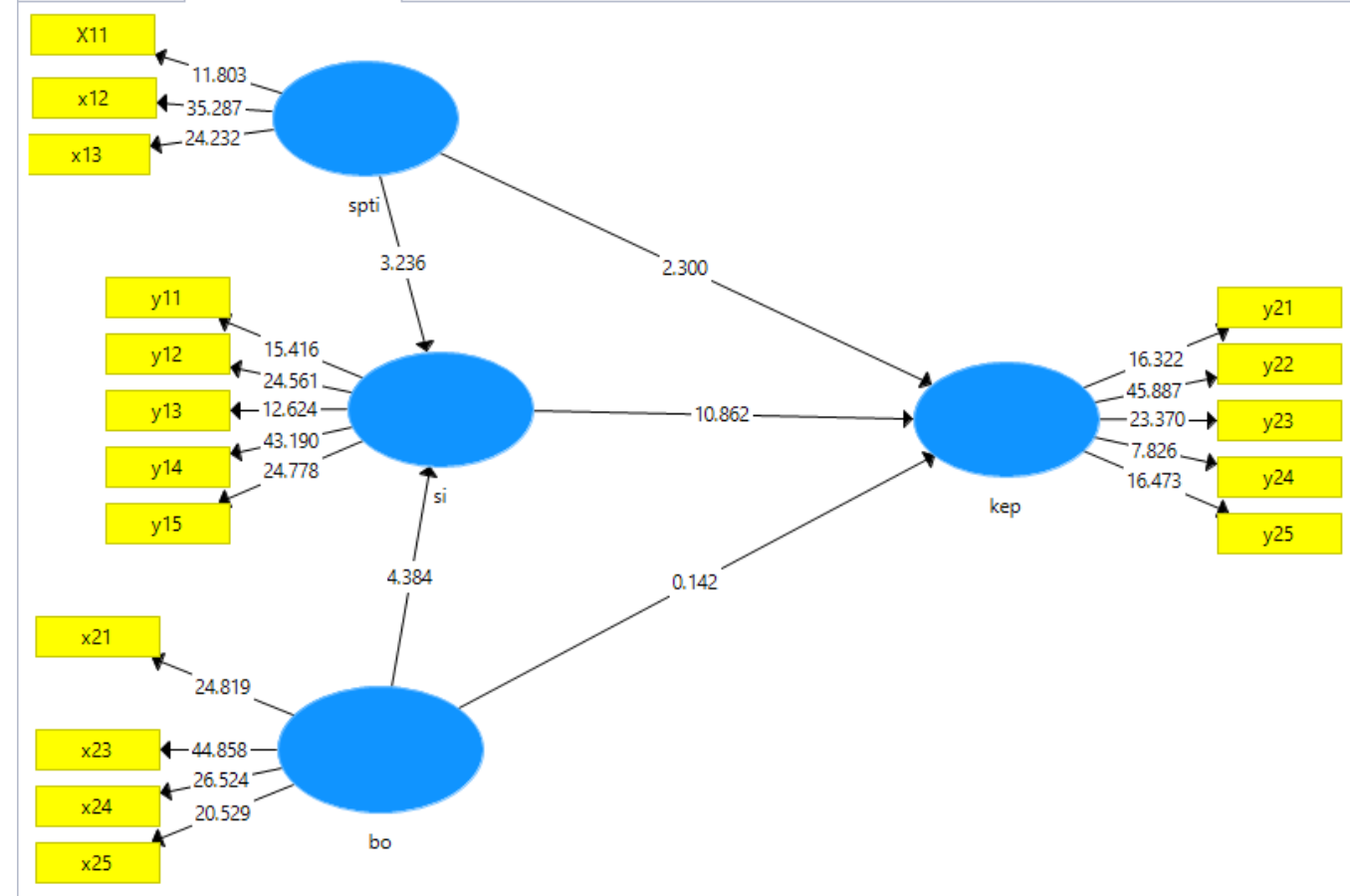

Gambar 2. Output Hasil PLS Boothstrapping

\section{Pengujian Hipotesis}

Menguji hipotesis dapat dilihat dari nilai t-statistik dan nilai probabilitas. Pengujian hipotesis yang menggunakan nilai statistik, maka untuk alpha 5\% nilai t-statistik yang digunakan adalah 1,96, sehingga kriteria penerimaan atau penolakan hipotesis adalah $\mathrm{H} 1$ diterima atau $\mathrm{H} 0$ ditolak ketika t-statistik $>1,96$. Penggunaan probabilitas dalam kriteria penerimaan atau penolakan hipotesis yaitu jika nilai $\mathrm{P}$ Values $<0,05$ maka $\mathrm{H} 1$ diterima dan $\mathrm{H} 0$ ditolak. 
Tabel 5. Koefisien Jalur

\begin{tabular}{|l|r|r|r|r|r|}
\hline & \multicolumn{1}{|c|}{ original sample } & sample mean & STDV & \multicolumn{1}{l|}{ T-Sta } & \multicolumn{1}{l|}{ P-Val } \\
\hline SPTI-> KEP & 0,187 & 0,184 & 0,081 & 2,300 & 0,022 \\
\hline BO-> KEP & 0,015 & 0,015 & 0,104 & 0,142 & 0,888 \\
\hline SPTI->SI & 0,357 & 0,359 & 0,110 & 3,236 & 0,001 \\
\hline BO->SI & 0,427 & 0,432 & 0,097 & 4,384 & 0,000 \\
\hline SI->KEP & 0,724 & 0,727 & 0,067 & 10,862 & 0,000 \\
\hline
\end{tabular}

Sumber: data diolah tahun 2020

1. Pada Gambar 7 dapat dilihat bahwa nilai original sample adalah sebesar 0,187 dengan signifikansi $<0,05$, dan nilai T statistik untuk Sarana Pendukung Teknologi Informasi terhadap Kepuasan Kerja sebesar 2,300 > $\mathrm{T}$ tabel $(1,960)$. Nilai original sample menunjukan nilai positif mengindikasikan bahwa Sarana Pendukung Teknologi Informasi berpengaruh positif terhadap Kepuasan Kerja. Dengan demikian H1 pada penelitian diterima.

2. Hasil pengujian ke dua nilai original sample adalah sebesar 0,015 dengan signifikansi < 0,05, dan nilai $\mathrm{T}$ statistik untuk Budaya Organisasi terhadap Kepuasan Kerja sebesar $0.142<\mathrm{T}$ tabel $(1,960)$. Nilai original sample menunjukan nilai positif mengindikasikan bahwa Budaya Organisasi berpengaruh Positif terhadap Kepuasan Kerja. Dengan demikian $\mathrm{H} 2$ pada penelitian ditolak.

3. Hasil pengujian ke tiga nilai original sample adalah sebesar 0.357 dengan signifikansi < 0,05, dan nilai T statistik untuk Sarana Pendukung Teknologi Informasi terhadap Sistem Informasi sebesar 3,236 > T tabel (1,960). Nilai original sample menunjukan nilai positif mengindikasikan bahwa Sarana Pendukung Teknologi Informasi berpengaruh positif terhadap istem Informasi. Dengan demikian H3 pada penelitian diterima.

4. Hasil pengujian hipotesis ke empat nilai original sample adalah sebesar 0.427 dengan signifikansi $<0,05$, dan nilai $\mathrm{T}$ statistik untuk Budaya Organisasi terhadap Sistem Informasi sebesar $4.384>\mathrm{T}$ tabel (1,960). Nilai original sample menunjukan nilai positif mengindikasikan bahwa Budaya Organisasi berpengaruh positif terhadap Sistem Informasi. Dengan demikian $\mathrm{H} 4$ pada penelitian diterima.

5. Hasil pengujian ke lima nilai original sample adalah sebesar 0.724 dengan signifikansi < 0,05, dan nilai $\mathrm{T}$ statistik untuk Sistem Informasi terhadap Kepuasan Kerja sebesar $10.862>\mathrm{T}$ tabel (1,960). Nilai original sample menunjukan nilai positif mengindikasikan bahwa Sistem Informasi berpengaruh positif terhadap Kepuasan Kerja. Dengan demikian H5 pada penelitian diterima.

\section{PENUTUP}

Didasarkan pada hasil analisis maka terdapat pengaruh positif signifikan antara Sarana Pendukung Teknologi Informasi terhadap Kepuasan Kerja, Sarana Pendukung Teknologi Informasi terhadap Sistem Informasi, Budaya Organisasi terhadap Sistem Informasi, dan Sistem Informasi terhadap Kepuasan Kerja. Namun Budaya Organisasi terhadap Kepuasan Kerja pengaruh positif tidak signifikan. 
Berdasarkan hasil penelitian yang telah dilakukan variabel Sarana Pendukung Teknologi Informasi berpengaruh positif signifikan terhadap variabel Kepuasan Kerja, mengandung implikasi bahwa penggunaan komputer dan sarana lain seperti kecepatan akses dan pelatihanpelatihan terhadap operator dapat meningkatkan kepuasan kerja dari Operator. Adanya sarana yang memadai dalam melakukan pekerjaan, akan mempermudah Operator dalam menjalankan segala pekerjaan, dan hal tersebut akan membuat Operator terpuaskan dalam melakukan pekerjaannya. Sedangkan hasil penelitian variabel Budaya Organisasi berpengaruh positif tidak signifikan terhadap variabel Kepuasan Kerja, mengandung implikasi bahwa budaya yang diterapkan dalam organisasi telah menjadi kewajiban bagi setiap anggotanya, sehingga budaya yang diterapkan disana tidak sepenuhnya menjadi sesuatu yang utama bagi kepuasan kerja Operator.

Hasil penelitian variabel Sarana Pendukung Teknologi Informasi berpengaruh positif signifikan terhadap variabel Sistem Informasi, mengandung implikasi bahwa penggunaan komputer dan sarana lain seperti kecepatan akses dan pelatihan-pelatihan terhadap operator dapat meningkatkan kecepatan informasi yang diperoleh oleh Operator. Hal tersebut membuktikan bahwa Sarana Pendukung akan mempermudah Operator dalam mengelola informasi dan sistem informasi berjalan dengan baik. Dan hasil penelitian variabel Budaya Organisasi berpengaruh positif signifikan terhadap variabel Sistem Informasi, Hal tersebut di implikasikan pada Budaya Organisasi yang diterapkan oleh telah membuat seluruh sistem atau pekerjaannya menjadi mudah dan nyaman bagi operatornya, sehingga salah satu sistem yang terapkan yaitu sistem informasi menjadi sesuatu yang terbiasa diterapkan dengan baik. Serta hasil penelitian variabel Sistem Informasi berpengaruh positif signifikan terhadap variabel Kepuasan Kerja, Hal tersebut membuktikan bahwa Sistem informasi yang aktual akan membuat pekerjaan lebih mudah diterima penerima informasi yang membuat mereka merasa puas dengan pekerjaannya yang berjalan dengan baik.

\section{DAFTAR PUSTAKA}

Ali dan Agustian, 2018, Analisa Pengaruh Budaya Organisasi Dan Gaya Kepemimpinan Terhadap Kepuasan Kerja Untuk Meningkatkan Kinerja Karyawan di Rumah Sakit Muhammadiyah Metro, Jurnal Ilmiah FE-UMM Economic Sciences Vol. 12 No. 2

Fendini, Dian Septiayu. 2013. Pengaruh Kualitas Sistem Dan Kualitas Informasi Terhadap Kepuasan Pengguna (Survei Pada Karyawan Pengguna Aplikasi Pelayanan Pelanggan Terpusat (AP2T) Di PT. PLN (Persero) Area Malang). Jurnal Administrasi Bisnis. Universitas Brawijaya Malang.

Ibrahim, M. Dan Dahlias, A. 2016. Pengaruh Fasilitas Kerja Terhadap Kepuasan Kerja Karyawan Pada Pt. Bank Riau Kepri Cabang Teluk Kuantan Kabupaten Kuantan Singingi, Jurnal Online Mahasiswa Bidang Ilmu Sosial Dan Ilmu Politik.

Mustika, Agnes Dan Utomo, Hardi. 2013. Pengaruh Budaya Organisasi, Terhadap Kinerja Karyawan Dengan Variabel Kepuasan Kerja Sebagai Variabel Intervening (Studi Kasus Pada Koperasi Simpan Pinjam Gradiska Kecamatan Tuntang Kabupaten Semarang Tahun 2013), Among Makarti Vol.6. 
Nelson, R. R., Todd, P. A., And Wixom, B. H. 2005. Antecedents Of Information And System Quality: An Empirical Examination Within The Context Of Data Warehousing. Management Information Systems, 21.

O’brien, James A. Dan George M. Marakas. 2009. Introduction To Information Systems. Fifteentb Edition. Mcgraw-Hill

Paramita, Anindita Dana. Suharnomo. Perdhana, Mirwan Surya. 2016. Analisis Pengaruh Servant Leadership Dan Budaya Organisasi Terhadap Kinerja Pegawai Dengan Kepuasan Kerja Sebagai Variabel Mediasi (Studi Pada Dinas PSDA Dan ESDM Kota Semarang), Jurnal Ekonomika Dan Bisnis Magister Manajemen Universitas Diponegoro

Pariyatin, Y. 2015. Pengaruh Penerapan Teknologi Informasi Terhadap Kualitas Pelayanan Di Kampung Sampireun Resort \& Spa, Jurnal Algoritma.

Rahmawati, Diana. 2010. Pengaruh Pemanfaatan Teknologi Informasi Terhadap Kualitas Pelayanan Pegawai Administrasi Dan Pengaruh Kualitas Pelayanan Pegawai Administrasi Terhadap Kepuasan Mahasiswa Di Lingkungan Fise Uny, Jurnal Pendidikan Akuntansi Indonesia, Vol. VIII.

Rasyid, Harun Al. 2017. Pengaruh Kualitas Layanan Dan Pemanfaatan Teknologi Terhadap Kepuasan Dan Loyalitas. Jurnal Eccodemica. Vol.1.

Robbins, Dan Judge, 2006, Organizational Behavior. New Jersey: Prentice Hall International, Inc

Rosnidah, I. 2010. Pengaruh Tingkat Pendidikan Auditor, Besarnya Kapuasan Dan Penggunaan Teknologi Informasi Terhadap Kepuasan Kerja Auditor Dan Implikasinya Pada Kualitas Audit (Survei Pada Kap Di Jakarta), Jakarta, Jurnal Akuntansi Universitas Tarumanegara Vol. 14.

Sugiyanto. Susanto, Djoko. 2018. Analisis Pengaruh Kompetensi, Sarana Pendukung Teknologi Informasi Dan Kepuasan Kerja Sebagai Variabel Intervening Terhadap Kinerja Sdm (Studi Kasus Kantor Pengawasan Dan Pelayanan Bea Dan Cukai Tipe Madya Pabean Semarang). Jurnal Manajemen. Universitas Semarang

Wirawan, 2015, Manajemen Sumber Daya Manusia Indonesia: Teori, Psikologi, Hukum Ketenagakerjaan, Aplikasi Dan Penelitian: Aplikasi Dalam Organisasi Bisnis, Pemerintahan, Dan Pendidikan. Jakarta: Pt Raja Grafindo Persada.

Wibowo, 2010, Manajemen Perubahan, Jakarta: Raja Grafindo Persada. 